\title{
SPEAKING CLUB AS AN INTERACTIVE EXTRACURRICULAR ACTIVITY IN LEARNING ENGLISH FOR PROFESSIONAL PURPOSES AT MEDICAL UNIVERSITIES
}

\author{
Oksana Demydovych \\ National University of "Kyiv-Mohyla Academy", Kyiv, Ukraine \\ o.demydovych@ukma.edu.ua \\ Olena Holik \\ Bohomolets National Medical University, Kyiv, Ukraine \\ elgolik88@gmail.com
}

\begin{abstract}
The article aims at evaluating the effectiveness of the Speaking Club in learning English for professional purposes at medical universities. The Speaking Club is presented as an integral part of the foreign language studies that, being a student-driven activity, promotes motivation as well as develops interaction and communication skills of its members. The authors define the concept of the Speaking Club based on the literature review and personal experience, find out effective ways of the Speaking Club organisation as well as describe its structure, roles and responsibilities of the participants. With regard to the management of the Speaking Club sessions, some important principles are defined in the present study. They deal with the interaction and communication style, moral beliefs and values, duration of the sessions and their planning, a topic choice and a format of the event. In the article, the emphasis is made on the main didactic principles applied to the preparation, organisation and hosting of the meetings and include visualisation, accessibility, active participation, systematisation and continuity. The authors carried out a five-year experiment to assess the effectiveness of the Speaking Club in terms of the language proficiency level of the participants and their social activity engagement. The study enrolled 140 students of the National Medical University named after O. O. Bohomolets and included 4 stages that lasted from 2012 to 2017. The research work delivers evidence of overall improvement of the four basic language skills (reading, writing, listening and speaking) and, therefore, a general increase in the English language proficiency level of the Speaking Club participants. According to the general conclusions drawn from the findings obtained before and after the experiment, the Speaking Club proves to be an effective extracurricular activity in learning English for professional purposes at medical universities.
\end{abstract}

Keywords: Speaking Club; interactive learning; active learning; student-driven learning; professional English.

\section{Introduction}

Due to economic globalisation, highly skilled professionals are not limited any more in their access to the international job market. Intense competition is observed among the job seekers whose qualifications must comply with high educational, professional and experience requirements for a job position. Ukraine is a part of the international job market due to its Pro-Western political course and active involvement in the international projects all over the world. New challenges have necessitated significant changes in the Ukrainian higher education. With regard to an increase in the overall competitiveness of the Ukrainian workforce, the University graduates are required to have their foreign language proficiency at a level B2 and higher. Depending on their future speciality, the University students complete a two or four-year foreign language course that is an integral part of any university training program. The intention to make learning active results from external (the need to pass exams) and internal factors including self-improvement, personal and professional growth, career development. Interactive application of various teaching techniques can be effectively realised on a regular basis through a preparation period and during the Speaking Club sessions. It is well-known that the Speaking Club ensures interactive and student-driven learning that increases the student motivation to master a foreign language.

Literature review. The Speaking Club as an interactive extracurricular activity in learning English for professional purposes is a relatively new concept in the academic environment. Many researchers investigated the issue of improving the quality of the English language teaching, introduced new interactive learning methods allowing the tutors to keep their students completely involved through mutual sharing of thoughts and knowledge, group and pair work as well as teaching and assessing each other. The scholars suggested benefits of the Speaking Club and offered their own understanding and definitions. Maksymenko (2017) described the English-Speaking Club for sociologists as a way to expand the vocabulary and discuss the present-day issues. Kovalova (2014) considered the Speaking Club as a new term in methodology, deserving special attention due to its potential and functionality. The foreign researchers suggested the terms "Discussion Club" or "Talk Club" (Alvermann et al., 1999) and "Public Speaking Club"

Demydovych, O. \& Holik, O. (2020). Speaking club as an interactive extracurricular activity in learning English for professional purposes at medical universities. Advanced Education, 14, 4-10. https://doi.org/10.20535/2410-8286.178238 
(Bjorklund, 1985) thus shifting the emphasis from linguistics to public speaking, exchanging thoughts, thinking skills, etc. However, the present study demonstrates that the application of this interactive extracurricular activity can be much wider because every session of the Speaking Club is unique, allowing the topic to rule over the format and teaching strategies.

Some researchers focused their attention on the investigation of the Speaking Club effectiveness. While studying different English learning methods, Chen and Goh (2011), Ananyeva (2014) and Renzulli et al. (2014), Hatcher-Skeers and Aragon (2002) came to the conclusion that interactive teaching technologies along with the student-driven education were major contributors to the successful foreign language learning. Some researchers emphasised on using interactive learning during the Speaking Club sessions. In the works of Boivan (2017), Zavaruyva (2018), Kovalova (2014), Maksymenko (2017) and Sherstova (2016), different aspects of the issue were outlined. Moruha \& Lymar (2011) and Shcherbyna (2011) dealt with additional methods of improving the active component of learning but these methods still need more profound investigation.

The out-of-class activities, including the Speaking Club (the Discussion Club or Communication Club), were studied by many researchers as an effective way of teaching not only English but many other subjects. Nguyen (2019) dwelt on the advantages of out-of-class teaching due to its higher learning effectiveness. Hauser (2008) comprehensively studied the ways of the Speaking Club organisation and described this activity as an effective method for the development of the language and interaction skills. Kasper and Kim (2015) stressed upon the necessity of teaching English not only in the classroom but also out of it, emphasising on the effectiveness of the Speaking Club. Malu and Smedley (2016) stated that the Speaking Club allowed the students to get familiar with the cultural peculiarities of the country and provided for better integration into the student society. Sorgen (2015) studied the effect of the Speaking Club onto the integration of refugees into society and found out its effectiveness for both language and social skills development. In their works, Alvermann et al. (1999), Bjorklund (1985) and Nunan (2001) underlined the importance of interaction between the students during their preparation for the English-Speaking Club sessions. In fact, the researchers pointed out that any student community and its meetings promoted the active learning. The importance of the Discussion Club for learning the basic vocabulary, as well as monologue and dialogue speaking, was shown by Zavaruyva (2018). Kovalova (2014) described the Speaking Club in the context of improving communication skills. Furthermore, according to Maksymenko (2017), the Speaking Club contributes to the development of basic language skills, thus allowing a person to speak a foreign language fluently. The necessity of interactive learning realised through the meetings of the English-Speaking Club was noted by Sivaieva and Temchenko (2005). The language schools developed guidelines for the organisation of the Speaking Club sessions (Club Leadership Manual, 2019), recognising the method as highly effective.

Based on the literature review and personal experience, the Speaking Club can be defined as an interactive extracurricular activity requiring the application of modern interactive teaching methods that support professional learning and knowledge, promote social exchange by the development of the basic language and interaction skills. The Speaking Club must be observed as an integral part of the foreign language studies that motivates students to learn English for professional purposes at universities. However, the concept of the Speaking Club as an interactive extracurricular activity should be studied for its effectiveness in terms of the foreign language proficiency level.

The aim of the present research is to study the effectiveness of the Speaking Club as an interactive extracurricular activity in learning English for professional purposes at medical universities. With regard to the aim of the present research, the following tasks were formulated: define the concept of the Speaking Club based on the literature review and personal experience; find out the effective ways of the Speaking Club organisation as well as describe its structure, roles and responsibilities of the participants; assess the effectiveness of the Speaking Club by estimating changes in both language proficiency level of the participants and their social activity engagement before and after the experiment.

\section{Methods}

Materials. Aimed at assessing the effectiveness of the Speaking Club as an interactive extracurricular activity in learning English for professional purposes at medical universities, the study needed the application of a combination of research methods. The qualitative method was used to consider thoughts, ideas, achievements (in the form of certificates, diplomas, letters of appreciation, or the level of satisfaction) of the participants in a biased way. The quantitative method was chosen to collect quantifiable data from the medical students, analyse the figures, and conduct inquiries, tests, interviews in an unbiased way. Both methods were used in the same ratio. 
Participants. The study enrolled 140 students of the National Medical University named after O.O. Bohomolets who made a community of undergraduates with the same interests and motivation. All participants were informed verbally about the details of the research and a signed written consent on being included in the experiment was received from each of them.

Procedure.The study that lasted from 2012 to 2017 was conducted to assess the effectiveness of the Speaking Club as an interactive extracurricular activity in learning English for professional purposes at medical universities. Thus, some stages were defined to make the experiment possible: 1) finding out the initial level of English among the participants of the Speaking Club before the experiment; 2) the Speaking Club sessions within a five-year period; 3) finding out the level of English among the participants of the Speaking Club after the experiment; 4) analysis of the obtained results.

The English language proficiency level of 140 students was assessed before (in 2012) and after the experiment (in 2017). The assessment was based on 4 basic language skills including reading, writing, listening and speaking. Each skill was evaluated according to the European accepted levels. The obtained data were statistically processed using the STATISTICA software.

The new pattern of the Speaking Club sessions was introduced and included interactive communication on medical issues organised as formal academic discussions and competitive tasks, mini-performances, and quizzes. The motto of the Speaking Club was: "Learn, play and entertain!" The sessions of the Speaking Club were held once a month from September to June. They were dedicated to various medical issues on History of Medicine, Vaccination, Robotic Medicine, Microsurgery, Tuberculosis, Infections in the Modern World, AIDS, Drugs and Drug Addiction, Alternative Medicine, etc. Participation in the Speaking Club sessions was voluntary, with the registration of the participants in the Speaking Club book.

The topic of the Speaking Club session predetermined its format and activities (tournaments, quizzes, brain-rings, performances, audio and video presentations followed by discussions, group problem solving). In spite of careful planning, no meeting went without the element of improvisation. The number of participants, their prior acquaintance with a subject, the course of discussions and presentations as well as the questions could not be predicted. Planning of each meeting was especially important for setting the time limitation. The duration of the event did not exceed two hours (120 minutes).

The activity of the Speaking Club underwent thorough and regular analysis. Along with other methods, the survey of the participants appeared to be a reliable way to find out strong and weak points. The section "Your recommendations" in the survey form allowed the organisers to get feedback from the participants for further important adjustments, modifications, and improvements in the work of the Speaking Club.

\section{Results}

From 2012 to 2017, 50 sessions of the Speaking Club were conducted at the National Medical University named after O. O. Bohomolets to find out the effectiveness of the Speaking Club as an interactive extracurricular activity in learning English for professional purposes at medical universities. The language skills of the participants were assessed before and after the experiment.

In 2012, the first-year students took an initial written test (reading, writing, listening sections), as well as personal interview to assess their English language proficiency level and place in the study groups of 1215 students of the same level. The results were used to get the information about the knowledge level of the Speaking Club participants that were enrolled in the present research. 140 students were selected randomly out of all participants of the Speaking Club. The findings are presented in Table 1.

Table 1. English language proficiency level of the Speaking Club participants, $1^{\star}$ year students, in 2012

\begin{tabular}{|l|c|c|c|c|}
\hline & $\begin{array}{c}\text { Pre-Intermediate } \\
\mathrm{B} 1, \%\end{array}$ & $\begin{array}{c}\text { Intermediate } \\
\mathrm{B} 2, \%\end{array}$ & $\begin{array}{c}\text { Upper-Intermediate } \\
\mathrm{B} 2+, \%\end{array}$ & $\begin{array}{c}\text { Advanced } \\
\text { C1, } \%\end{array}$ \\
\hline Speaking & 12 & 52 & 28 & 8 \\
\hline Reading & 14 & 56 & 20 & 10 \\
\hline Writing & 21.5 & 43 & 30 & 5.5 \\
\hline Listening & 26 & 42 & 24.5 & 7.5 \\
\hline Total & 18.4 & 48.3 & 25.3 & 8 \\
\hline
\end{tabular}

Before the experiment, the majority of the students (48.3\%) had the Intermediate level of English or B2, $25.3 \%$ - the Upper-Intermediate level or B2+, 18.4\% - the Pre-Intermediate level or B1 and only $8 \%$ showed the Advanced level of English or C1. It is worth noting that the detailed analysis of the test results in the 
listening section demonstrated almost equal share of those with the pre-intermediate and upper-intermediate level ( $26 \%$ and $24.5 \%$ respectively), and only $7.5 \%$ of the students had the advanced level of English in this section. With regard to their speaking skills, the total majority of the participants demonstrated the intermediate level (52\%), 12\% of the students had the pre-intermediate level, and 8\% - the advanced level of English.

In 2017, 140 fifth-year students, who were enrolled in the study, took a final written test (reading, writing, listening sections), as well as personal interviews to determine their progress. The findings are presented in Table 2.

Table 2. English language proficiency level of the Speaking Club participants, $5^{\text {th }}$ year students, in 2017

\begin{tabular}{|l|c|c|c|c|}
\hline & $\begin{array}{c}\text { Pre-Intermediate } \\
\text { B1, } \%\end{array}$ & $\begin{array}{c}\text { Intermediate } \\
\text { B2, } \%\end{array}$ & $\begin{array}{c}\text { Upper-Intermediate } \\
\text { B2 }+, \%\end{array}$ & $\begin{array}{c}\text { Advanced } \\
\text { C1, \% }\end{array}$ \\
\hline Speaking & 2.3 & 15.2 & 36 & 46.5 \\
\hline Reading & 5.1 & 12.9 & 31 & 51 \\
\hline Writing & 6.9 & 16 & 35 & 42.1 \\
\hline Listening & 7 & 10 & 44 & 39 \\
\hline Total & 5.3 & 13.5 & 36.5 & 44.7 \\
\hline
\end{tabular}

Significant progress can be observed. The number of students with the Upper-Intermediate and Advanced level of English increased and amounted to $36.5 \%$ and $44.7 \%$ respectively. It is worth mentioning that 42 students passed their international language examinations and were awarded the language proficiency certificates confirming the English level $\mathrm{C}$. The number of the students with the Pre-Intermediate and Intermediate level of English decreased to 5.3\% and 13.5\% respectively. Overall improvement of the four language skills was found.

\section{Discussion}

The Speaking Club is one of the most effective extracurricular activities at medical universities as it provides lots of benefits for its participants. However, it requires hard work, much effort and commitment from its mentor (a faculty member) and executive board. The faculty members should realise the importance of switching from the conservative, dogmatic and authoritarian style of teaching to partnership relations with their students.

Voluntariness, accurate planning, regularity, high expertise, openness, and personal interest should be typical features of the Speaking Club. It should consist of 1) a group of the active members including the faculty members and the students who make up the executive board of the Speaking Club, 2) participants and 3) special guests (experts). The executive board is responsible for the organisation of the sessions that is realised through accurate scheduling and planning, information delivery and exchange, the invitation of experts. The praesidium consists of the faculty members and invited experts and/or practising specialists, who comment on the content, group and individual contribution of the students. The participants are involved in the report production and delivery, discussions, competitive tasks, mini-performances, dramas and etc. The original information sources (scientific publications, video presentations (for example, TED talks), movies or their fragments) should be used at the Speaking Club sessions.

In the framework of this study, it is necessary to describe the structure of the executive board that ensures the effective functioning of the Speaking Club. The President is responsible for the following aspects: monitoring of all aspects of the Speaking Club operation as well as inter-university cooperation; organisation and coordination of the Speaking Club subdivisions; control of the social activity engagement of the students and quality of their participation. In cooperation with the mentor, who represents the faculty, the President comes up with an annual plan for events and discussions and hosts the sessions. The President makes monthly and annual reports about the Speaking Club operation. There are several Deputies working for the research and analytical subdivisions. They assist the President in all aspects of his/her work. The Deputy President for public relations and the Press Secretary are responsible for publications, press-releases, promotion, reporting, webpage content, communication with the students via social networks. The Coordinator deals with the inter-university cooperation by organising an active participation of the students from other Ukrainian universities in the Speaking Club sessions, helping them with accommodation. The coordinator is also responsible for setting up relations with the foreign students, who often are native English speakers. The technical aspects of the event management lie within the responsibility of the Coordinator. 
Such hierarchy effectiveness is evidenced by the successful work of the Speaking Club at the National Medical University named after O. O. Bohomolets.

The active members (executive board) are elected annually, based on their own initiative, language proficiency level (not lower than B2 level) and ideas in terms of the Speaking Club popularisation and development. Anyone, who is interested in self-growth, can be a participant, regardless of their language proficiency level. The idea of constant and neverending improvement supported by Robbins' (2019) investigation was implemented in the form of three main rules: 1 ) do your best; 2 ) behave appropriately; 3 ) show an interest and gratitude.

The study is coherent with the research results presented by Zavaruyva (2018). The scholar states that the Speaking Club provides all the necessary capacity for monologue and dialogue speech practice as well as involves the participants in active, problematic, direct and indirect learning. The main didactic principles are applied to the preparation, organisation and hosting of the event and include visualisation(application of diagrams, graphs, roadmaps, mind-maps, infographics, scribing, storytelling and etc.), accessibility (the topics correspond to the general level of professional expertise and language proficiency of the participants so that they do not experience serious difficulties during any session), conscious and active participation (voluntary involvement in the Speaking Club activities and intensive participation in the cognitive educational process), systematisation and continuity (interrelation between the teaching and the training stages or connecting theory with practice).

With regard to the management of the Speaking Club sessions, some important principles were defined in the present study. They deal with the interaction and communication style, duration of the meetings and other aspects that are presented below.

There are three main rules that everyone is advised to follow during the Speaking Club sessions:

1. Mistakes are never corrected to develop confidence and fluency in the foreign language. The participants improve their language skills by listening, speaking, reading and writing and not by having their mistakes corrected.

2. Demonstrate mutual respect and tolerance by avoiding discrimination against participants on the basis of their race, religion, age, and lifestyle.

3. Provide support and encouragement to every participant.

The Speaking Club meetings should be rigorously planned. The topics should be agreed for the whole year. The aspects of each topic should be discussed at the working meetings. For instance, in medical universities, modern advances in medicine or lifetime achievements and legacy of famous scientists can be suggested as the main topic of the year.

The student participation is greater if the topics of choice complement the academic curriculum. For instance, during the first two years of studies, some English classes are dedicated to the anatomy of gastrointestinal tract and pathologies of the digestive system, their diagnosis, treatment, and prevention. That is why the Speaking Club session on new technologies and discoveries in gastroenterology would be a suitable addition. In such case, all participants would have enough theoretical knowledge and adequate topic vocabulary to take an active part in the Speaking Club session.

The study supports the stipulation, introduced by Sorgen (2015), according to which the Speaking Club is both language and ethical education project because, in addition to the language aspects, social issues should be taken into account during a preparation period and the event itself. The well-placed accents form the moral stance of the youth, encourage their patriotism (the military conflict in eastern Ukraine, volunteering, terrorism) and develop their proper attitude towards globalisation (global warming and climate change).

Some improvements were defined in terms of the social activity engagement. Due to increased English language proficiency level, the social activity engagement of the students has grown over time. Before the experiment, it was described as rather low due to the students' poor self-organisation, passive attitude to the Speaking Club sessions and unstable motivation. The pattern changed within a five-year period. Moreover, the Speaking Club participants began to collaborate with numerous national and foreign official institutions, agencies and organisations. They provided language assistance for the central military medical authority department of Ukraine, the US Embassy and DIMO (Institute of Medical Operations of the HS of the USA), the UK Embassy, the state Ukrainian organisation "Patriots Protection" (program "First Responders"), the Ministry of Health of Ukraine and the Ministry of Defense of Ukraine.

The Speaking Club participants served as interpreters during the WHO workshops. All these activities are confirmed by appropriate certificates and award letters. Active collaboration with the international medical and military agencies in terms of military actions in the East of Ukraine provides enough evidence of increased responsibility and high moral values and beliefs of the Speaking Club participants. 
The experiment was initially carried out with the purpose of improving hard skills of the medical students which promote increasing their English language proficiency level. As a result, soft skills also underwent sustainable development. A 5-year experiment has become a piece of additional evidence that proves the scholars' general opinion that the Speaking Club as an interactive extracurricular activity is an effective way to develop not only hard skills but also soft skills that are highly demanded in the XXI century. Communication and presenting skills, networking, teamwork and collaboration, creativity and critical thinking, mediation and negotiation, emotional intelligence were practised by the students during the sessions.

The aim of the research was achieved by the completion of the outlined tasks. Due to the comparative analysis of the results, obtained before and after the experiment, the effectiveness of the Speaking Club in both language proficiency level of the participants and their social activity engagement was proved. In addition, the research confirms the findings of the scientific investigations, reviewed in this paper, claiming that the Speaking Club as a project or an extracurricular activity can be used to improve not only the English language proficiency but to promote the knowledge of any other medical discipline. The topics, structure, instructions, session frequency can be changed and altered according to the students' needs.

\section{Conclusions}

The literature review and personal experience allow us to conclude that the Speaking Club should be an integral part of the foreign language studies at universities as it, being a student-driven, promotes motivation as well as develops interaction and communication skills of its members.

The Speaking Club can be defined as an interactive extracurricular activity requiring the application of modern interactive teaching methods that support professional learning and knowledge, promote social exchange by the development of the basic language and interaction skills.

In the framework of the present research, the effective ways of the Speaking Club organisation, as well as its structure, roles and responsibilities of the participants, were investigated and described. With regard to the management of the Speaking Club sessions, some important principles were defined.They deal with the interaction and communication style, moral beliefs and values, duration of the sessions and their planning, a topic choice and a format of the event. The emphasis is made on the main didactic principles applied to the preparation, organisation and hosting of the meetings and include visualisation, accessibility, conscious and active participation, systematisation and continuity. The most productive structure of the Speaking Club is represented by a group of the active members including the faculty members and the students (the President, his/her Deputies and the Coordinator) who make up the executive board of the Speaking Club, participants and special guests (experts).

The study was conducted to assess the effectiveness of the Speaking Club as an interactive extracurricular activity in learning English for professional purposes at medical universities. The findings demonstrated an overall improvement of the four basic language skills (reading, writing, listening and speaking) and, therefore, a general increase in the English language proficiency level of the Speaking Club participants. The obtained data give us evidence of the effectiveness of the Speaking Club in learning English for professional purposes.

The social activity engagement growth was observed as well due to the active participation of the Speaking Club members in the work of the national and foreign official institutions, agencies and organisations. That is why the Speaking Club can be referred to as a language and ethical education project.

The perspective for further research. It is necessary to conduct further empirical research on the Speaking Club effectiveness in the linguistic competence formation in terms of various specialities.

References:

Alvermann, D. E., Young, J. P., Green, C., \& Wisenbaker, J. M. (1999). Adolescents' perceptions and negotiations of literacy practices in after-school read and talk clubs. American Educational Research Journal, 36(2), 221-264. https://doi.org/10.3102/00028312036002221

Ananyeva, M. (2014). A Learning Curriculum: Toward Student-Driven Pedagogy in the Context of Adult English for Academic Purposes, English for Specific Purposes, and Workplace English Programs. TESOL Journal, 5(1), 8-31. https://doi.org/10.1002/tesj.73

Bjorklund, D. (1985). Dignified joking: humor and demeanor in a public speaking club. Symbolic Interaction, 8(1), 3346.https://doi.org/10.1525/si.1985.8.1.33

Bojvan, O. (2017). Formuvannja humanno-tsinnisnyx orijentatsij u studentiv tehnichnykh special'nostej u procesi vyvchennja inozemnoji movy u formati anhlomovnykh klubiv [Development of humanity values in technical students during studying foreign language within the English Speaking Club formats]. Zbirnyk naukovyx prats' Umans'koho derzhavnoho pedahohichnoho universytetu [Collection of scientific works of Umanskiy pedagogical university], 2(1), 57-65. Retrieved 2 January 2020 from: http://znp.udpu.edu.ua/article/view/134395

Chen, Z., \& Goh, C. (2011). Teaching oral English in higher education: Challenges to EFL teachers. Teaching in Higher Education, 16(3), 333-345. https://doi.org/10.1080/13562517.2010.546527 
Club Leadership Manual (2019). The Effortless English Club. Retrieved March 20, 2019 from http://www.effortlessenglishclub.com/ podcast/Club-Leadership-Manual.pdf

Hatcher-Skeers, M. \& Aragon, E. (2002). Combining active learning with service learning: a student-driven demonstration project. Journal of chemical education, 79(4), 462. https://doi.org/10.1021/ed079p462

Hauser, E. (2005). Footing and identity in interaction at a conversation club. The Consequences of Mobility: Linguistic and Sociocultural Contact Zones, 28-44. Retrieved 2 January 2020 from: https://core.ac.uk/download/pdf/12521180.pdf

Hauser, E. (2008). Nonformal institutional interaction in a conversation club: Conversation partners' questions. Journal of Applied Linguistics and Professional Practice, 5(3), 275-295. http://doi.org/10.1558/japl.v5i3.275

Kasper, G. (2004).Participant orientations in conversation-for-learning. Modern Language Journal, 88(4), 551-567. http://doi.org/10.1111/j.0026-7902.2004.t01-18-.x

Kasper, G., \& Kim, Y. (2015). Conversation-for-learning: Institutional talk beyond the classroom. In Numa Markee (Ed.),The handbook of classroom discourse and interaction (pp.390-408). https://doi.org/10.1002/9781118531242.ch23

Koval’ova, Ye. (2014). Razgovornyiy klub na angliyskom yazyike po ekonomike kak effektivnyiy sposob formirovaniya i razvitiya kommunikativnoy kompetentsii studentov neyazyikovyih ekonomicheskih vuzov [Language English club in Economics as an effective way of forming and developing communicative competence of students studying at non-linguistical economical universities]. Dostizheniya vuzovskoy nauki, 11, 70-73. Retrieved 2 January 2020 from: https://elibrary.ru/item.asp?id=21875725

Kurhila, S. (2001). Correction in talk between native and non-native speakers. Journal of Pragmatics, 33(7), $1083-1110$. http://doi.org/10.1016/S0378-2166(00)00048-5

Maksymenko, O. (2017). Spetsializovanyi rozmovnyi klub anhliiskoi movy yak zasib pidvyschennia rivnia movlennievoi kompetentsii sotsiolohiv [Specialised language English club as a means of increasing the level of language competence of sociologists]. In V.Glushchenko\& V.Tkachenko (Eds.), Yakisna movna osvita u suchasnomu hlobalizovanomu sviti: tendentsii, vyklyky, perspektyvy: materialy I Vseukrainskoi naukovo-praktychnoi konferentsii [High-quality language education in modern globalised world: trends, challenges, perspectives. Proceedings of I All-Ukrainian scientific-practical conference] (pp. 87-91). Sumy: Sum.DU.Retrieved 2 January 2020 from: http://essuir.sumdu.edu.ua/handle/123456789/67134

Malu, K. F. \& Smedley, B. (2016). Community-based English clubs: English practice and social change outside the classroom. English Teaching Forum, 54(3), 10-23. Retrieved 2 January 2020 from https://americanenglish.state.gov/resources/englishteaching-forum-volume-54-number-3\#child-2162

Moruha, K. \& Lymar, L. (2011). Aktyvizatsiia piznavalnoi diialnosti studentiv pry vyvchenni inozemnykh mov u nemovnomu vyschomu navchalnomu zakladi [Activization of learning activity of students while learning foreign languages in nonlinguistic high educational establishments]. Naukovi zapysky Natsionalnoho pedahohichnoho universytetu imeni M. P. Drahomanova. Seriia: Pedahohichni ta istorychni nauky, 95, 154-159. Retrieved 2 January 2020 from http://enpuir.npu.edu.ua/handle/123456789/5077

Nguyen, Ch. T. (2019). Enhancing the Quality of Foreign Language Learning Through Extracurricular Programs for Vietnamese Students.Education and linguistics research, 5(2), 1-20. https://doi:10.5296/elr.v5i2.14980

Nunan, D. (2001). Action Research in Language Education. In David R. Hall \& A. Hewings (Eds.), Innovation in English Language Teaching: A Reader (pp.180-191). London: Routledge. https://doi.org/10.4324/9781315011561

Renzulli, J., Gentry, M., \& Reis, S. (2014). Enrichment clusters: A practical plan for real-world, student-driven learning. US, Texas: Prufrock Press.

Scherbyna, I. (2011). Formuvannia sotsiokulturnoi kompetentsii uchniv pry orhanizatsii pozaklasnoi roboty z inozemnoi movy [Developing social-cultural competence of the students while organising after-class studies in foreign languages]. In V.V. Zhukovska, \& V.I.Savchuk (Eds.), Suchasni napriamky doslidzhen mizhkulturnoi komunikatsii ta metodyky vykladannia inozemnykh mov: Zbirnyk naukovykh prats 3 vseukrayinskoi naukovoyi konferentsii [Modern directions in studies of the crosscultural communication and methods of teaching foreign languages: Scientific Proceedings of the $3^{\text {rd }}$ All-Ukrainian Scientific Conference] (pp.426-430). Zhytomyr, XhDU. Retrieved 2 January 2020 from: http://eprints.zu.edu.ua/5847/1/426-430.pdf

Sherstova, K. (2016). Speaking Club - bilshe mozhlyvostei dlia vyvchennia anhliiskoi movy [Speaking Club - more opportunities for learning English]. In S.O. Krasnikova, \& L.V.Miroshnik (Eds.), Metodolohiia ta praktyka linhvistychnoi pidhotovky inozemnykh studentiv: zbirnyk materialiv Mizhnarodnoi naukovo-praktychnoi konferentsii27 kvitnia 2016 [Methodology and practice of language training of foreign students. Proceedings of the International Scientific-Practical Conference 27 April 2016] (pp.192-193). Kharkiv: KhNMU. Retrieved 2 January 2020 from http://repo.knmu.edu.ua/handle/123456789/15061

Sivaieva, N. \& Temchenko, L. (2005). Vykorystannia innovatsiinykh tekhnolohii u hrupovii pozaklasnii roboti z inozemnoi movy u ZNZ [Using innovative technologies in group after-class learning foreign languages at schools]. Visnyk Zhytomyrskoho derzhavnoho universytetu imeni Ivana Franka, (24), 206-207. Retrieved 2 January 2020 from http://eprints.zu.edu.ua/3763/1/05snprim.pdf

Sorgen, A. (2015). Integration through participation: The effects of participating in an English conversation club on refugee and asylum seeker integration. Applied Linguistics Review, 6(2), 241-260.https://doi.org/10.1515/applirev-2015-0012

Zavaruyva, I. (2018). Language debatable club as additional resource to studying of foreign language. Linguistics. Lingvoculturology, 12(1), 13-22. Retrieved from https://lingvodnu.com/index.php/journal/article/view/66 